\title{
Genus-Specific Identification of Enterococci by PCR Method
}

\author{
Š. CUPÁKOVÁ ${ }^{1}$, M. POSPÍŠILOVÁ ${ }^{1}$, I. KOLÁČKOVÁ ${ }^{2}$, R. KARPÍŠKOVÁ ${ }^{2}$ \\ 'Department of Milk Hygiene and Technology, Faculty of Veterinary Hygiene and Ecology, \\ University of Veterinary and Pharmaceutical Sciences Brno, Czech Republic \\ ${ }^{2}$ National Institute of Public Health Prague, Centre of the Hygiene of Food Chains
}

Received May 6, 2005

Accepted November 10, 2005

\begin{abstract}
Cupáková Š., M. Pospíšilová, I. Koláčková, R. Karpíšková: Genus-Specific Identification of Enterococci by PCR Method. Acta Vet Brno 2005, 74: 633-637.

The aim of this study was to verify the application of polymerase chain reaction method focused on the detection of genus-specific tuf-gene for the rapid identification of enterococci. The reaction was as duplex-PCR, when, apart from the detection of genus-specific tuf-gene (amplification product of $112 \mathrm{bp}$ ), the internal control for 16S rRNA gene (amplification product of $241 \mathrm{bp}$ ) was also inserted. Detection of $t u f$-gene was positive in Enterococcus spp. isolates from the collections of microorganisms ( 8 species) and in 283 field isolates from foods and food raw materials, drinking water and various kind of waste water, previously identified by phenotypic methods as enterococci of different species. PCR product of $112 \mathrm{bp}$ was missing in 16 non-enterococci strains and in 14 field isolates thereafter identified as lactococci. The above PCR method can be recommended for the rapid identification of enterococci in the routine use.
\end{abstract}

Enterococcus spp., polymerase chain reaction, tuf-gene

The identification of enterococci, using conventional methods and biochemical tests based on their phenotypic characteristics, is complicated and time-consuming (Devriese et al. 1993). Not only in clinical, but also in food microbiology, the methods of molecular biology focused on the genus or species identification of enterococci (Dutka-Malen et al. 1995; Ke et al. 1999), intra-generic typing of enterococci isolated from foods (Suzzi et al 2000; Andrighett to et al. 2001) or faecal samples and rectal swabs of farm and pet animals (Devriese et al. 1996), begin to be applied in the sample examination.

Ke et al. (1999) have developed a PCR method for rapid genus-specific identification of enterococci, which is based on the detection of $t u f$-gene encoding the elongation factor $\mathrm{Tu}$ (EF-Tu). EF-Tu is a GTP-binding protein playing a central role in the protein synthesis. In the bacterial genome, there is one up to three tuf-genes present in various copy numbers, when only one is present in the majority of gram-positive bacteria with the low GC content (Ke et al. 2000). During the further study of tuf-gene sequence in 17 species of enterococci, two different sequence variants of $t u f$-genes ( $t u f \mathrm{~A}$ and $t u f \mathrm{~B}$ ) were described. The tufA-gene was proved to be present in all tested species, which enables its successful application as the target sequence in drafting the genus-specific PCR method (Ke et al. 2000).

The aim of this study was to verify the application of PCR method based on the detection of genus-specific tuf-gene for the rapid identification of enterococci isolated from foods, food raw materials and other environmental samples.

\section{Materials and Methods}

Bacterial isolates

Total of 297 field isolates of enterococci from foods and food raw materials, drinking water and various kinds of agriculture and sewage waste water were used in the study. The basic isolations were carried out by the plate method streaking $0.1 \mathrm{ml}$ of sample or their dilutions on plates with the Slanetz-Bartley agar (S-B agar, HiMedia 
Table 1. Species and origin of isolates tested in the study

\begin{tabular}{|l|rrrrrrrrr|r|}
\hline \multirow{2}{*}{ Species } & \multicolumn{8}{c|}{ Number of isolates from individual sources* } \\
\cline { 2 - 9 } & A & B & C & D & E & F & G & H & Total \\
\hline Enterococcus faecalis & 13 & 10 & 6 & 8 & 2 & 0 & 2 & 58 & 99 \\
Enterococcus faecium & 3 & 0 & 19 & 2 & 3 & 2 & 0 & 15 & 44 \\
E. Group III. (durans/hirae) & 26 & 5 & 1 & 1 & 0 & 0 & 0 & 13 & 46 \\
Enterococcus mundtii & 14 & 22 & 16 & 0 & 0 & 0 & 0 & 6 & 58 \\
Enterococcus casseliflavus & 14 & 4 & 0 & 0 & 0 & 0 & 0 & 0 & 18 \\
Enterococcus malodoratus & 0 & 1 & 1 & 0 & 0 & 0 & 0 & 0 & 2 \\
Enterococcus saccharolyticus & 6 & 4 & 0 & 0 & 0 & 0 & 0 & 0 & 10 \\
Enterococcus solitarius & 2 & 0 & 0 & 0 & 0 & 0 & 0 & 0 & 2 \\
Enterococcus gallinarum & 0 & 1 & 0 & 0 & 0 & 0 & 0 & 0 & 1 \\
Enterococcus spp. & 0 & 0 & 4 & 0 & 1 & 0 & 4 & 8 & 17 \\
Total & 78 & 47 & 47 & 11 & 6 & 2 & 6 & 100 & 297 \\
\hline
\end{tabular}

*A - raw milk, milk products, B - beef, sausage batter, meat products, $\mathrm{C}$ - common carp (fillets),

$\mathrm{D}$ - delicatessen, $\mathrm{E}$ - confectionary, $\mathrm{F}$ - spices, $\mathrm{G}$ - drinking water, $\mathrm{H}$ - agricultural and municipal waste water

Laboratories Pvt. Ltd., Bombay, India). Plates were incubated aerobically at $37{ }^{\circ} \mathrm{C}$ for 48 hours. The detailed overview of analyzed isolates is in Table 1. The method was verified using the group of 21 different strains (Streptococcus, Staphylococcus, Listeria, Bacillus, Rhodococcus, Escherichia, Proteus, Pseudomonas, Salmonella, and Shigella) acquired from the Czech Collection of Microorganisms (Brno, The Czech Republic) and from the National Institute of Public Health Prague (Czech Republic) (Table 3).

Table 3. Verification of PCR specificity using collection strains of microorganisms

\begin{tabular}{|c|c|c|c|}
\hline Gram-positive bacteria & $\begin{array}{c}\text { PCR } \\
\text { product } \\
112 \mathrm{bp}\end{array}$ & Gram-negative bacteria & $\begin{array}{c}\text { PCR } \\
\text { product } \\
112 \mathrm{bp}\end{array}$ \\
\hline Enterococcus faecalis CCM 4224 & + & Escherichia coli CCM 3954 & - \\
\hline Enterococcus faecium CCM 2308 & + & Proteus vulgaris CCM 1799 & - \\
\hline Enterococcus durans CCM 5612 & + & Pseudomonas aeruginosa CCM 3955 & - \\
\hline Enterococcus hirae CCM 2423 & + & Salmonella Enteritidis CCM 4420 & - \\
\hline Enterococcus mundtii CCM 4059 & + & Shigella flexneri CCM 4422 & - \\
\hline Enterococcus malodoratus CCM 4057 & + & & \\
\hline Enterococcus raffinosus CCM 4216 & + & & \\
\hline Enterococcus casseliflavus CCM 2401 & + & & \\
\hline Streptococcus agalactiae CCM 6187 & - & & \\
\hline Streptococcus uberis CCM 4617 & - & & \\
\hline Staphylococcus aureus CCM 6188 & - & & \\
\hline Staphylococcus intermedius NRL 03/087 & - & & \\
\hline Staphylococcus hyicus NRL 96/422 & - & & \\
\hline Staphylococcus schleiferi subsp. coagulans NRL 00/762 & - & & \\
\hline Listeria monocytogenes CCM 4699 & - & & \\
\hline Listeria innocua CCM 4030 & - & & \\
\hline Listeria ivanovii CCM 5884 & - & & \\
\hline Bacillus cereus CCM 2010 & - & & \\
\hline Rhodococcus equi CCM 3429 & - & & \\
\hline
\end{tabular}

The following tests were used for the identification of isolates: Gram staining, catalase production, morphology of colonies on blood agar (Blood Agar Base No.2, HiMedia Laboratories Pvt. Ltd., Bombay, India; and sheep blood, Bioveta, a.s., Ivanovice na Hané, Czech Republic), growth on S-B agar and Bile Aesculin agar (Oxoid, Basingstoke, Hampshire, England). Selected isolates were identified using the ENCOCCUStest (Pliva-Lachema, a. s., Brno, 
Czech Republic), by the production of pyrolidonyl arylamidase (PYRAtest, Pliva-Lachema, a. s., Brno, Czech Republic), by the motility and by the production of pigment.

Isolation of bacterial DNA

For each individual isolate, 24-h culture from a blood agar incubated aerobically at $37^{\circ} \mathrm{C}$ was used. The DNA isolation was carried out by the boiling the bacterial suspension (density of 1 degree of MacFarland scale) in sterile distilled water at the temperature $100{ }^{\circ} \mathrm{C}$ for $20 \mathrm{~min}$ with the consecutive spinning at $13000 \mathrm{rpm}$ for $10 \mathrm{~min}$. Supernatant was used as a template.

Polymerase chain reaction

Enterococcus spp. identification was carried out by a modification procedure described by Ke et al. (1999). The reaction was designed as duplex-PCR, when, apart from the detection of genus-specific tuf-gene (product size 112 $\mathrm{bp}$ ), the internal control was also inserted. The sequence of the internal control was derived from the 16S rRNA gene (product size $241 \mathrm{bp}$ ) and is universal for any bacterial species (Martine au et al. 1996). The reaction mixture $(25 \mu 1)$ contained: $1 \mu 1$ of the template, $12.5 \mu 1$ PPP Master Mix (Top-Bio, s.r.o., Prague, The Czech Republic) with the $\mathrm{MgCl}_{2}$ to the final concentration of $2.5 \mathrm{mM}, 1 \mu \mathrm{M}$ primers Ent1 and Ent2, $0.2 \mu \mathrm{M}$ primers InKo1 and InKo2 (Generi Biotech s.r.o., Hradec Králové, Czech Republic). Sequences of applied primers are in Table 2. The strain Enterococcus faecalis CCM 4224 was used as the positive control, the strain Escherichia coli CCM 3954 was used as the negative control.

Table 2. Primers used

\begin{tabular}{|llll|}
\hline Primer & Sequence & Product size & Reference \\
\hline Enterococcus spp. & & & \\
Ent1 & 5' - TAC TGA CAA ACC ATT CAT GAT G - 3' & & \\
Ent2 & 5 ' - AAC TTC GTC ACC AAC GCG AAC - 3' & 112 bp & Ke et al., 1999 \\
Internal control & & & \\
InKo1 & 5 ' - GGA GGA AGG TGG GGA TGA CG - 3' & & \\
InKo2 & 5' - ATG GTG TGA CGG GCG GTG TG - 3' & 241 bp & Martineau et al., 1996 \\
\hline
\end{tabular}

The PCR amplification passed in the termocycler PTC-200 (MJ Research Watertown, Massachusetts, USA) according to the following program: the initial denaturation $94{ }^{\circ} \mathrm{C} / 2 \mathrm{~min}$, amplification -30 cycles $\left(94{ }^{\circ} \mathrm{C} / 30 \mathrm{~s}\right.$, $55^{\circ} \mathrm{C} / 15 \mathrm{~s}, 72^{\circ} \mathrm{C} / 30 \mathrm{~s}$ ), final extension $72{ }^{\circ} \mathrm{C} / 4 \mathrm{~min}$. The products were analyzed by the gel electrophoresis in $2.0 \%$ agarose (Serva Electrophoresis GmbH, Heidelberg, Germany) with the consecutive staining with ethidium bromide and visualization on the UV transilluminator. DNA marker 155 - 970 bp (Top-Bio, s.r.o., Prague, The Czech Republic) was used as molecular weight standard.

\section{Results and Discussion}

Our study is based on the work of Ke et al. (1999) and Martineau et al. (1996). We adjusted the PCR method enabling a rapid genus identification of enterococci based on the detection of the genus-specific tuf-gene and detection of the 16S rRNA gene as internal control. Specifity of the method was verified using the group of 19 gram-positive and 5 gram-negative control collection strains (Table 3 and Plate XIII, Fig. 1). A total of 291 enterococci of various species, isolated from foods, food raw materials, other environmental samples, and acquired from the strain collection (Table 1 and Table 3 ), were confirmed as enterococci. In none of the non-Enterococcus isolates a product of $112 \mathrm{bp}$ was detected.

Detection of the tuf-gene was negative in group of 14 isolates from carp fillets, namely, 11 isolates identified phenotypically as E. faecium, 1 isolate of E. Group III and 2 isolates of Enterococcus spp. These isolates yielded dubious or negative results of PYRAtest and a poor ability to grow on Bile Aesculin agar. During the initial isolation on S-B agar the isolates grew in small-sized red colonies with a prolonged growing time (48 - $72 \mathrm{~h}$ ). Slower growth in small-sized grey colonies was also observed on blood agar. In the laboratory of the Czech Collection of Microorganisms, these isolates were reclassified as Lactococcus spp.

The plating method is commonly used to establish the number on S-B agar aerobically at $37^{\circ} \mathrm{C}$ for the period of $24-48 \mathrm{~h}$. After incubation red-up-to-brown colonies are being 
counted. With subcultivation of characteristic colonies from S-B agar on blood agar, the time necessary to acquire final results, is approximately $30 \mathrm{~h}$, with phenotypic identification it is $48 \mathrm{~h}$. Unambiguous identification by method PCR required only $4 \mathrm{~h}$. Švec and Sedláček (1999) state that the morphology of enterococci colonies on S-B agar is significantly variable, even in individual species. Furthermore, the authors state that $17 \%$ of strains isolated from S-B agar were not enterococci; these were unspecified grampositive cocci and both gram-positive and gram-negative rods. Devriese et al. (1993), Leclerc et al. (1996) and also Franz et al. (1999) identically point out the close relationship of enterococci, streptococci and lactococci. Patel et al. (1998) describes a close relationship of the species Enterococcus solitarius and bacteria Tetragenococcus spp. For standardization of the enterococci plate count procedure in foods, and to prevent eventual mistakes in reading the results, the application of highly specific confirmation tests is necessary.

The PCR method based on the detection of tuf-gene has been found specific and suitable for the genus confirmation of enterococci isolated from foods and environmental samples. Apart from the initial costs of the equipment, the PCR method itself, owing to the easy DNA isolation by boiling and use of commercial PPP Master Mix, is a low-cost and time saving procedure. The method described in this paper can thus be recommended for the routine identification of bacteria Enterococcus spp.

\section{Rodová identifikace enterokoků metodou PCR}

Cílem studie bylo ověrit možnost využití metody polymerázové řetězové reakce zaměřené na průkaz rodově specifického tuf-genu pro rychlou identifikaci enterokokủ. Reakce byla koncipována jako duplex-PCR, kdy mimo detekce rodově specifického tuf-genu (amplifikační produkt o velikosti 112 bp) byla zařazena i interní kontrola na bázi genu pro 16S rRNA (amplifikační produkt o velikosti $241 \mathrm{bp}$ ). Detekce tuf-genu byla pozitivní u izolátů Enterococcus spp. pocházejících ze sbírky mikroorganismů ( 8 druhů) a u 283 izolátů z potravin a potravinových surovin, pitné vody a různých druhů odpadních vod, které byly dříve fenotypovými metodami identifikovány jako enterokoky různých druhů. PCR produkt o velikosti 112 bp nebyl detekován u 16 kmenů jiných rodů než Enterococcus spp. a u 14 izolátů posléze identifikovaných jako laktokoky. Uvedenou PCR metodu lze jednoznačně doporučit pro rutinní použití přii rychlé identifikaci enterokokủ.

\section{Acknowledgements}

The authors are thankful to MVDr. Alena Lorencová, Ph.D. of the Veterinary Research Institute in Brno for providing strains necessary for the study, and RNDr. Ivo Sedláček, CSc. of the Czech Collection of Microorganisms Brno for the identification of problematic strains.

This study was supported by the project of Ministry of Education, Youth and Sports of the Czech Republic No. MSM6215712402 Veterinary Aspects of Food Safety and Quality.

\section{References}

ANDRIGHETTO C, KNIJFF E, LOMARDI A, TORRIANI S, VANCANNEYT M, KERSTERS K, SWINGS J, DELLAGLIO F 2001: Phenotypic and genetic diversity of enterococci isolated from Italian cheeses. J Dairy Res 68: $303-316$

DEVRIESE LA, IEVEN M, GOOSSENS H, VANDAMME P, POT B, HOMMEZ J, HAESEBROUCK, F 1996: Presence of vancomycin-resistant enterococci in farm and pet animals. Antimicrob Agents Chemother 40: 2285-2287

DEVRIESE LA, POT B, COLLINS MD 1993: Phenotypic identification of the genus Enterococcus and differentiation of phylogenetically distinct enterococcal species and species groups. J Appl Bacteriol 75: $399-408$

DUTKA-MALEN S, EVERS S, COURVALIN P 1995: Detection of glycopeptide resistance genotypes and identification to the species level of clinically relevant enterococci by PCR. J Clin Microbiol 33: 24-27

FRANZ CHMAP, HOLZAPFEL WH, STILES ME 1999: Enterococci at the crossroads of food safety? Int J Food Microbiol 47: 1-24 
KE D, BOISSINOT M, HULETSKY A, PICARD FJ, FRENETTE J, OUELLETTE M, ROY PH, BERGERON MG 2000: Evidence for horizontal gene transfer in evolution of elongation factor Tu in enterococci. J Bacteriol 182: 6913-6920

KE D, PICARD FJ, MARTINEAU F, MÉNARD CH, ROY PH, OUELLETTE M, BERGERON MG 1999: Development of a PCR assay for rapid detection of enterococci. J Clin Microbiol 37: 3497-3503

LECLERC H, DEVRIESE LA, MOSSEL DAA 1996: Taxonomical changes in intestinal (faecal) enterococci and streptococci: consequences on their use as indicators of faecal contamination in drinking water. J Appl Bacteriol 81: 459-466

MARTINEAU F, PICARD FJ, ROY PH, OULLETTE M, BERGERON MG 1996: Species-specific and ubiquitous DNA-based assays for rapid identification of Staphylococcus epidermidis. J Clin Microbiol 34: 2888-2893

PATEL R, PIPER KE, ROUSE MS, STECKELBERG JM, UHL JR, KOHNER P, HOPKINS MK, COCKERILL III FR, KLINE BC 1998: Determination of 16sRNA sequences of enterococci and application to species identification of nonmotile Enterococcus gallinarum isolates. J Clin Microbiol 36: 3399-3407

SUZZI G, CARUSO M, GARDINI F, LOMBARDI A, VANNINI L, GUERZONI ME, ANDRIGHETTO C, LANORTE MT 2000: A survey of the enterococci isolated from an artisanal Italian goat's chesse (semicotto caprino). J Appl Microbiol 89: 267-274

ŠVEC P, SEDLÁČEK I 1999: Occurrence of Enterococcus spp. in waters. Folia Microbiol Prague 44: 3-10 

Plate XIII

Cupáková Š. et al.: Genus-Specific Identification ... pp. 633-637

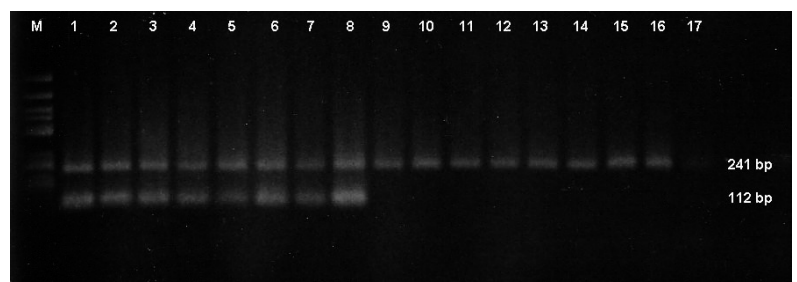

Fig. 1. Verification of PCR specificity using collection strains of gram-positive and gram-negative microorganisms

Line M: DNA marker 155 - 970; lines 1 - 8: Enterococcus faecalis CCM 4224 (1), Enterococcus faecium CCM 2308 (2), Enterococcus durans CCM 5612 (3), Enterococcus hirae CCM 2423 (4), Enterococcus mundtii CCM 4059 (5), Enterococcus malodoratus CCM 4057 (6), Enterococcus raffinosus CCM 4216 (7), Enterococcus casseliflavus CCM 2401 (8); lines 9-16: Streptococcus agalactiae CCM 6187 (9), Streptococcus uberis CCM 4617 (10), Staphylococcus aureus CCM 6188 (11), Listeria monocytogenes CCM 4699 (12), Bacillus cereus CCM 2010 (13), Salmonella Enteritidis CCM 4420 (14), Escherichia coli CCM 3954 (15), Pseudomonas aeruginosa CCM 3955 (16); line 17: negative control. 